\title{
The tiger's retreat
}

\section{Tigers are teetering on the verge of extinction and human contact in their habitat could be their greatest threat. Erika Check investigates whether local people can live alongside India's big cats.}

$t$ is the dry season in southern India, but a thunderstorm has cooled the air and damped down the dust in the forest of Nagarhole National Park in Karnataka. As he drives slowly down a dirt road in the park, wildlife biologist Ullas Karanth keeps one eye on the horizon and the other on the wet ground, scanning for tiger tracks.

Through a thicket of bamboo, we spot a young elephant ambling across a marsh. Karanth stops the jeep. The only sounds are barbets cooing from the trees and the frenzied cry of a cuckoo nicknamed the brain-fever bird. Karanth murmurs, "This used to be a bustling little village... 30,40 houses, lots of cultivation....." He doesn't finish his sentence, but his meaning is clear: now the people are gone, the wildlife is coming home to where it belongs.

We drive on, scanning the underbrush for any movement. Suddenly, Karanth hits the brakes and exclaims in an excited whisper:

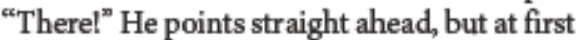
I don't see it. A herd of spotted deer stands alerted by the road, about 20 metres ahead. I follow their eyes, and that's when I see him: the world's largest cat, pacing across the road.

I yelp; Karanth shushes me. But the tiger continues at his leisurely pace through the grassy clearing. I catch only a glimpse of his massive head and striped flanks before he disappears into the dense lantana and the woods beyond. The deer advance nervously after him, checking to make sure he's gone. Karanth shakes my hand. "You are really lucky, he says. "I have seen tigers so many

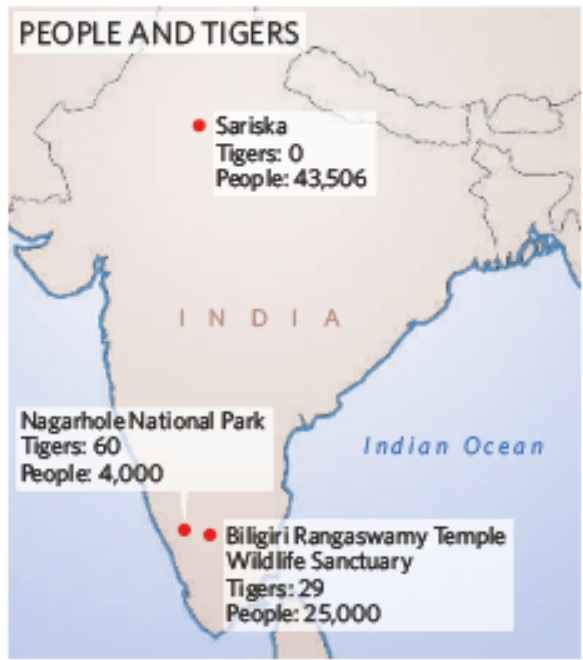

times, but each time it is like a special event."

For Karanth, each sighting is doubly satisfying, because his work in Nagarhole is part of the reason why tigers still exist there today. Karanth was the first Indian scientist to do rigorous tiger ecology in India. During his 20 years of work, he combined research with relentless activism to keep people and poachers away. And tigers have thrived there.

In the rest of India, the big cat has not been so lucky. A century ago, 40,000 tigers roamed India's forests and grasslands. Now, the Indian government estimates that only 3,600 still exist - and most informed observers say the number is probably between 1,200 and 2,000 (see 'Counting cats', overleaf). India's tiger population is teetering on the brink of extinction.

This is a tragedy, and not only for the tiger. The big cat is a source of national pride in India and a part of the country's identity. The tiger is also an umbrella species - a high-profile animal that earns protection for the other animals that live alongside it. This means that the same forces that threaten the tiger also bring bad news for many other vulnerable species in India, such as the rare Indian giant squirrel and the massive forest ox, the gaur. 


\section{COUNTING CATS}

How many tigers are left in India? That depends on whom you ask. Since 1966, the Indian governmenthas used the 'pugmark census' to track the beasts. Every few years, forest officials roam through every national park for one to two weeks looking for pawprints. They assign prints to individual tigers to arrive at a total count. The government's most recent estimate, four years ago, was 3,642 animals.

But biologists heapscorn on the pugmark census, saying it is virtually impossible to find tracks from every tiger in such a short time, or to tell the animalsapart by their prints ${ }^{3}$.
Instead, most scientists have argued that the government should use sampling methods and statistics to monitor tiger populations. As recently as 2004 , Project Tiger director Rajesh Gopal flatly dismissed critics of the pugmarkmethod and slammed the alternative photographing and counting the animals with remotely triggered cameras. But after the embarrassing revelation last year that there were no tigers in Sariska National Park, Rajasthan - despite the government's claim that there were between 16 and 18 tigers there in 2004 Project Tiger was forced to make concessions. Project Tiger has devised a monitoring strategy that involves both sampling and counting methods, and said lastyear that it would have an accurate estimate of India's tiger population by this July. But even the revised strategy has drawn heavy fire from international tiger biologists. Last month, Project Tiger relented under their criticism, halted its count temporarily, and said it would take at least another year to issue its final report. In the meantime, some conservationists think India's tiger population could be as low as 1,200 animals. E.C.
The reasons behind the tiger's decline are complex rampant poaching; a lack of funding for the country's network of tiger reserves, a sclerotic and bureaucratic system of park management; the constant pressure of more people; and more development, such as industrialscale mining in forests. Some scientists suggest that the government's distrust of conservation science is also behind the decline.

\section{Tribal trouble}

The conflict has led to emotional, seemingly intractable debates over the central question of tiger conservation in India: can tigers and people live together? Some, like environmentalist Sunita Narain, who led a government task force on tigers last year, say there is no choice. Today, 380,535 people live in India's 37,761 square kilometres of tiger reserves. Tigers and poor people live in the same spots, and both have rights to the land. But Karanth and other die-hard conservationists argue that tigers and people will never coexist peacefully.

Faced with this bleak picture, some have given up on the tiger's future. But not Karanth, who has watched the animals recover from seemingly hopeless odds in some places.

Karanth first visited Nagarhole in 1967, on a motorcycle trip during college. He hardly saw a deer, let alone a tiger. Logging and hunting were rampant. And India's tourism department was still luring visitors to the country by promising that they could shoot a tiger and take it home as an exotic souvenir.

But the animal's fate was not sealed. In 1972 , Prime Minister Indira Gandhi convened a task force to study India's disappearing tigers. The group's report expanded into the programme called Project Tiger. Today, that programme is responsible for the animal's survival in India, and controls a sprawling complex of 28 tiger reserves - from Namdhapa, on the eastern border with Burma, to Kalakad-Mundanthurai, at the southern tip in Tamil Nadu state.

Wildlife continued to fascinate Karanth as he pursued an engineering degree. After just three years working as an engineer, he realized he hated his career and changed course, leaving to do a $\mathrm{PhD}$ in wildlife biology at the University of Florida. He returned to Nagarhole in 1986 - this time, as a young scientist gathering data for a research project.

By that time, new park managers, led by forest officer K. M. Chinnappa, were working to stamp out poaching and enforce new wildlife protection laws. Nagarhole was starting to bounce back, and Karanth wanted to test its potential as tiger habitat. But undertaking a science project in the park was not easy. Chinnappa fought constant skirmishes with the 'tribals', groups of forest dwellers who lived by hunting, herding livestock and collecting firewood. Poachers, too, were angry that their prime hunting grounds were now off-limits.

Early on, Karanth and Chinnappa realized they shared a mission. Karanth had started a project to count tiger prey, from the tiny spotted deer to the hulking gaur. By figuring out how much tiger food was roaming around

Nagarhole, Karanth reasoned, he could predict how many tigers could live there.

But the studies were interrupted in 1992, when simmering tensions erupted into violence. An angry mob of villagers stormed the park, burned Chinnappas house down, and vandalized Karanth's research station. A local man was murdered in the aftermath of the riot, and officials arrested Chinnappa for the crime. Although he was later cleared, Chinnappa was done with the forest department. He began working instead as a wildlife activist in the villages in and around Nagarhole, as well as in other national parks in the larger state of Karnataka. Karanth, too, realized that he could not do his science in isolation. Since then, he has worked with Chinnappa and other activists to ensure that Nagarhole and other parks remain untouched.

\section{Numbers game}

Today, Nagarhole has one of the healthiest tiger populations in India - about 60, by Karanth's estimation. He attributes that to both a crackdown on poaching and an effort to relocate 12 villages outside the park.

Karanth's belief that the tiger needs an inviolate habitat comes partly from his research. In the 1980s and early 1990s, Karanth perfected his method of counting prey to predict tiger populations, but absolute confirmation - by radio-collaring every tiger in the Nagarhole forests - wasn't feasible. So he decided to capture the animals another way: on film.

Karanth adapted a device called the Trailmaster, designed to help hunters find deer. It had an infrared sensor that, if tripped, triggers a camera to capture the passing animal's image. Karanth installed a handful of Trailmasters at Nagarhole and spent the next decade working with statisticians to estimate the tiger population based on the number of tripped sensors ${ }^{1}$. "There is no doubt in trapping, is widely used in my mind that we need wildlife biology.

to do a lot to save the tiger - as much as we need to do to save poor people who live with the tiger." - Sunita Narain
Karanth's latest research, which combines ten years' worth of data, strengthens his conviction. In unpublished work, he estimates that over the past decade, an average of $23 \%$ of the park's tigers have died or left the park every year. And yet the population is stable, partly because females breed often. To Karanth, this underlines the importance of keeping people out and sustaining prey populations for the tiger. "It's very resilient," he says. "But you can't have people, and you can't have cows."

Sweeping social and demographic shifts, 


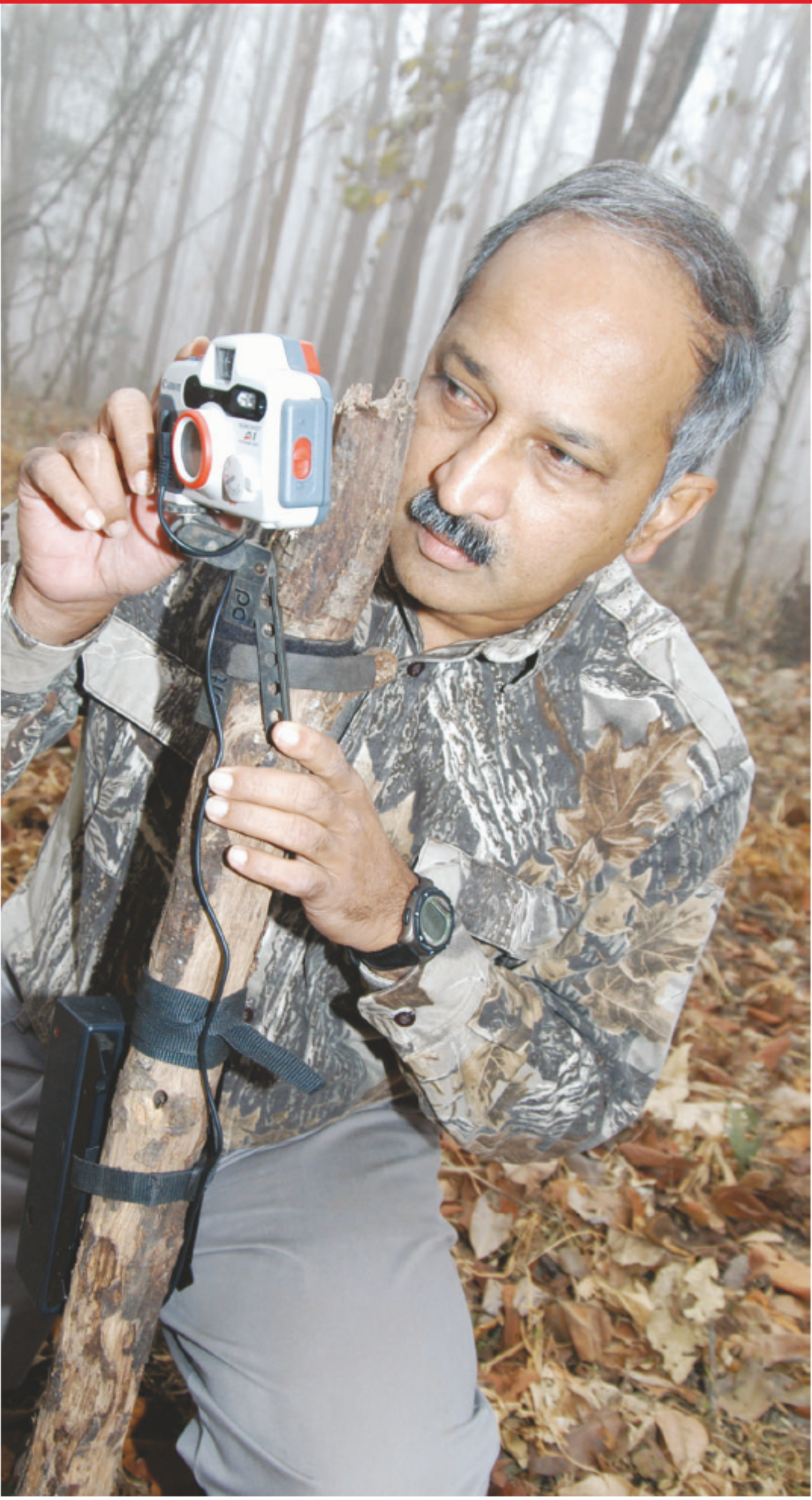

Candid camera:Ullas Karanth sets up camera traps to measure tiger numbers at Nagarhole.

however, are not in Karanth's favour. One billion people live in India, with a projected population of 1.6 billion by 2050 . And the country's push towards social reform is empowering groups that have been traditionally disenfranchised.

In the past, tribal groups living alongside tigers were simply pushed off their land by the government. The forced relocations often left whole villages stranded with no way to make a living; villagers came right back to the forest. Now some scientists are asking whether there should be a different solution - some way for tigers and people to coexist.

\section{Peaceful coexistence}

Not far from Nagarhole lies a test case for coexistence, in the Biligiri Rangaswamy Temple Wildlife Sanctuary - BRT for short - in Karnataka. Inside the sanctuary are 540 square kilometres of rolling hills, rainforest, coffee plantations, and thousands of members of the Soliga tribal group. In 1972, when the sanctuary was created, the government moved 25,000 Soligas into small settlements called podus in and around the park. Now, they support themselves by harvesting lichens, fruits, honey and other forest products.

In one podu near the southern tip of the sanctuary, a group of Soliga women and children sits in a dirt yard circled by papaya, banana and mango trees. The women point out a shed with a dried-grass roof. Inside, stacks of burlap sacks bulge with lichens collected from the forests. It takes one week for a harvester to fill one sack, which earns the village 500 rupees - about US $\$ 10$. The harvesters pass the lichens on to a central cooperative that sells them and distributes the profits within the community.

Little evidence of profits can be seen in this podu. The houses are constructed of mud and sticks, and villagers must rebuild the grass roofs each year. The women wear tattered saris and are afraid to send their children to the school a few kilometres away because elephants might trample them on the way. A deep trench encloses the village; it's supposed to keep the elephants from raiding the crops. But if elephants don't get to the crops, marauding packs of wild boars do.

There is a new hospital an hour's drive away. But no one in the village owns a car, and they can't afford the 30-rupee bus fare. So what happens when someone gets sick? "We just die, says one Soliga woman, with a bitter laugh.

And yet the Soliga do not want to leave this podu. The state government has offered to resettle families on 300 hectares of land outside the sanctuary. But the men and women in this podu say they won't go. They are attached 
to their god, who lives in a hill that looms over the village. And they won't leave their temple, a spare, dirt-floored hut. ${ }^{\alpha}$ They have relationships with gods here, and they have burial sites within the sanctuary," says C. Madhegowda, an activist. Madhegowda, who is also a Soliga, explains: "We are children of the forest. We are not interested in leaving."

\section{Meeting halfway}

Madhegowda works with a group that is standing up to the government in ways that might have been unthinkable a few decades ago. In 2003 , India banned the harvest of non-timber forest products from wildlife sanctuaries. In the past, the Soligas might have just accepted this removal of their main source of income. But not now. Madhegowda's group organized strikes in the Karnataka state capital, Bangalore, and met with officials in the forest department. For now, there is an informal détente that allows harvesting to continue in the sanctuary. ${ }^{\alpha}$ Twenty-five thousand people depend on this harvest," Madhegowda says. "You can't ban that if you don't provide an alternative."

The Soligas say they should be allowed to stay because they're not harming the park. Over the past decade, a Bangalore-based organization called the Ashoka Trust for Research in Ecology and the Environment (ATREE) has been working with the Soligas on sustainable harvesting practices. ATREE researchers have reported that the Soligas make accurate estimates of their harvest, and rarely use harmful methods, such as cutting branches off fruit trees. As a result, populations of harvested plants and bees have been relatively stable over the past decade ${ }^{2}$.

ATREE researchers hope this will convince the state forest department to allow the Soliga to help manage the wildlife sanctuary where they live. "We're saying these people can take responsibility for managing this park," says Nitin

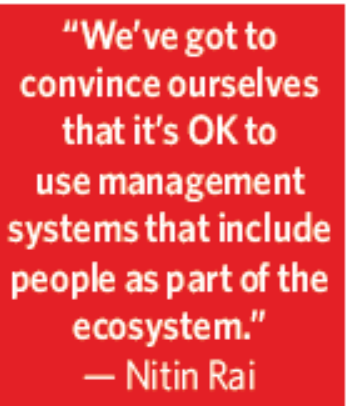

Big cat country: tourists on elephant back can watch tigers atclose proximity in some of India's tiger reserves.

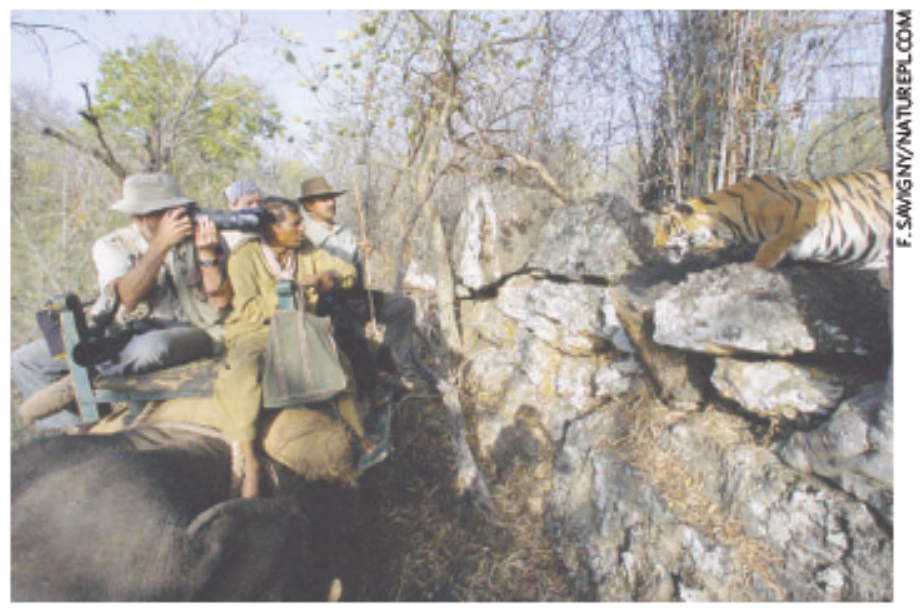

and the government's appointment of a task force to examine India's tiger crisis. "We've got to convince ourselves that it's OK to use management systems that include people as part of the ecosystem," Rai says.

A year-and-a-half ago, Sunita Narain would have taken Rai's side against Karanth. The outspoken activist has taken on some of the most powerful interests in India in her fight for environmental justice. Last year, her high profile and political connections earned her the job of chairing the prime minister's task force on Project Tiger. Narain's appointment was controversial, because she was an outsider to the tiger community.

Narain's unenviable task was to find some middle ground between the two camps of the tiger debate. And she believes the group did find a good compromise. Its final report estimated it would cost between US $\$ 713$ million and US $\$ 2.5$ billion to move every person out of India's tiger reserves. The task force instead suggested the government pick the most crucial areas of habitat and concentrate on moving people away from those places first. In the rest of the areas, the task force suggested that the Rai, an ecologist and sociologist with ATREE.

Rai started out as a 'wildlifer' like Karanth, but now believes it is not realistic to manage tiger populations by moving people out of their way. He points to the antagonistic relationships that have sprung up around some of the tiger reserves, where villagers are so alienated from the park's mission that they happily serve as paid guides for poachers. Such antagonism notoriously led to the poaching of every tiger from a reserve called Sariska in Rajasthan. The revelation last year that all Sariska's tigers were gone led to a public outcry, government find ways for people and tigers to coexist, as some say they do in the Biligiri Rangaswamy Hills.

For Narain, this was a huge concession. ${ }^{\alpha}$ Coming into this as an environmentalist, I definitely thought that relocation was not the solution," she says. "But we tried to meet the conservationists halfway." And she stresses that the relocations, if they are done, should be done well. The villagers should be given good land, and enough money to make an honest go at a new life. This is a sore point in India, where government-run relocations are often botched, leaving people in worse circumstances than those they left behind.

\section{Feasible futures}

On that point, Karanth agrees with Narain. The day after our tiger sighting in Nagarhole, we are up before dawn, driving to the forestdepartment quarters to meet a park official. There Karanth lays out a stern directive: he is trying to work out a deal to move one of the last villages out of Nagarhole - and he wants the forest department on his side. "Yes, yes," the forest official agrees, nodding as Karanth spells out his plans. But this is only one step, and many months of negotiations will follow.

Later, Karanth drives us past some of the villages that were relocated years ago to the outskirts of Nagarhole. There are neat rows of houses, and fields where men drive ploughs pulled by cows. Karanth sees this as inevitable progress. After all, he asks, should people live as the Soligas do forever - with no electricity, no hospital and no schools?

Some of the voices in the tiger debate disagree with Karanth's methods. But most now agree with his premise: that saving the Indian tiger also means helping the people who live alongside it. "There is no doubt in my mind that we need to do a lot to save the tiger - as much as we need to do to save poor people who live with the tiger," Narain says. "The poverty of each is leading to the poverty of the other.

Where possible, this will mean Karanth's strategy of relocating people to improve their welfare. Elsewhere, scientists, activists and officials must find other ways to end the antagonism between tigers and people. Otherwise, both species face a desperate future.

Erika Check is Nature's biomedical correspondent

1. Karanth KU, Nichols I.D, Kumar, N.S, Link, W.A.\&

Hines IE Proc Natt Acad Soj USA 101, 4854-4858(2004)

2 Shanker, K, Hiremath, A.\&Bawa, K. PLoS Bial. 3, e394 (2005)

3 Karanth, K. U.etal. Anim. Behav. 6, 141-146 (2003) 